\title{
PELAKSANAAN PENDIDIKAN POLITIK OLEH DPD PARTAI GERINDRA JAWA TIMUR DALAM RANGKA MENGHADAPI PEMILU SERENTAK 2019 (Studi Pada DPC Partai Gerindra Kabupaten dan Kota Mojokerto)
}

\author{
Halimur Rosyid \\ Fakultas Ilmu Sosial dan Ilmu Politik \\ Universitas Islam Darul Ulum Lamongan \\ h.rasyid88@gmail.com
}

\begin{abstract}
General election Simultaneously 2019 is a challenge and opportunity for all elements of the nation in improving the political system and democracy in Indonesia, that is the reason that became the basis of the East Java Gerindra Party to carry out political education in Mojokerto. This study aims to describe the implementation of political education for three times with qualitative descriptive methods and interactive analysis. The results of this study reveal that the objectives and material presented in the implementation of political education are still oriented towards strengthening internal party institutions as an effort to strengthen ideology, winning strategies and internal party consolidation. In addition, the obstacles that arise are methods of inappropriate communication and limited time of activity.
\end{abstract}

Keywords: Simultaneous elections, Political Education, Gerindra Party

Abstrak: Pemilihan umum serentak 2019 menjadi tantangan dan peluang bagi seluruh elemen bangsa dalam perbaikan sistem politik dan demokrasi di Indonesia, alasan itulah yang menjadi dasar Partai Gerindra Jawa Timur melaksanakan pendidikan politik di Mojokerto. Penelitian ini bertujuan untuk mendeskripsikan pelaksanaan pendidikan politik selama tiga kali dengan metode deskriptif kualitatif dan analisis interaktif. Hasil penelitian ini mengungkapkan bahwa tujuan dan materi yang disampaikan pada pelaksanaan pendidikan politik masih berorientasi pada penguatan kelembagaan internal partai sebagai usaha untuk penguatan ideology, stratefi pemenangan dan konsolidasi internal partai. Selain itu, hambatan yang muncul adalah metode komunikasi yang kurang tepat dan keterbatasan waktu kegiatan.

Kata kunci: Pemilu serentak, Pendidikan Politik, Partai Gerindra

\section{PENDAHULUAN}

Pendidikan politik merupakan serangkaian aktifitas yang bertujuan untuk membentuk dan menumbuhkan orientasi politik pada individu berupa keyakinan konsep, pengetahuan dan wawasan politik yang bermuatan politis, sehingga mampu menggerakkan seseorang untuk memiliki kesadaran terhadap persoalan politik dan sikap politik. Jika hubungkan dengan partai politik, pendidikan politik dapat dimaknai sebagai upaya sadar dan tersistematis dalam mentransformasikan segala hal yang terkait dengan perjuangan partai politik, agar tujuan untuk memberikan kesadaran kepada mereka $r$ akan pentingnya peran dan fungsi, serta hak dan kewajibannya sebagai manusia atau warga negara.

Sistem politik kita telah menempatkan partai politik sebagai salah 
satu pilar penyangga demokrasi. Kehadiran partai politik dalam negara demokrasi tidak dapat lepas dari peran dan fungsi partai politik itu sendiri. Ramlan Surbakti (2010:149) menyatakan bahwa fungsi utama partai politik adalah mencari dan mempertahankan kekuasaan guna mewujudkan program-program yang disusun berdasarkan ideologi tertentu. Namun selain untuk mencari dan mempertahankan kekuasaan, partai politik juga memiliki peranan sebagai wadah sosialisasi politik atau instrument of political socialization. Secara harfiah, sosialisasi merupakan upaya memasyarakatkan sesuatu menjadi dikenal dan dipahami oleh masyarakat, sedangkan sosialisasi politik ialah proses pembentukan sikap dan orientasi politik para anggota masyarakat (Muhadam Labolo, 2015:20), dari pengertian tersebut dapat dipahami bahwa pendidikan politik merupakan satu dari kesekian fungsi partai politik yang wajib untuk dilaksanakan guna mendukung peningkatan partisipasi masyarakat dalam kegiatan politik.

Selain itu, pelaksanaan pemilihan umum juga menjadi indikator dalam sistem demokrasi, karena masyarakat bisa berpartisipasi dalam menentukan pilihan politiknya terhadap proses pemerintahan dan kenegaraan. Dalam sejarah perjalanan bangsa Indonesia, pemilu menjadi tujuan nyata dalam mewujudkan tegaknya demokrasi, pemilu juga menjadi hajatan lima tahunan untuk mengganti kekuasaan dan kepemimpinan ditingkat nasional, dimana partai politik bisa saling berkompetisi untuk mendapatkan simpati rakyat dalam memperoleh kekuasaan politik (legislatif dan eksekutif) yang sah secara undang-undang dan konstitusional.

Persoalaanya, semenjak reformasi, sistem pemilu di Indonesia terus mengalamai berbagai pergeseran, hal ini karena kebutuhan akibat perkembangan dan situasi politik bangsa. Sistem pemilu yang dianut di Indonesia sebelumnya adalah sistem pemilu yang dilakukan dalam tahapan pemilu legislatif (pileg), pemilu presiden (pilpres) serta pemilihan kepala daerah provinsi dan kabupaten/kota (pilkada). Pemisahan sistem pemilu, dianggap oleh beberapa kalangan kurang efektif dan efisien dalam mendukungun penguatan pemerintahan sistem presidensial, karena menimbulkan berbagai persoalan, seperti konflik antara berbagai kepentingan kelompok dan individu, pemborosan anggaran, money politic atau politik uang, politisasi birokrasi, dan juga tingginya intensitas kegiatan elction di Indonesia yang tentu saja berdampak pada rendahnya tingkat partisipasi pemilih akibat kejenuhan publik.

Sedangkan, sistem pemilu yang akan dilaksanakan tahun 2019 berdasarkan Putusan Nomor 14/PUUXI/2013 Perihal uji materi UU Nomor 42 Tahun 2008 tentang Pemilihan Umum Presiden dan Wakil Presiden, telah memiliki konsekuensi lahirnya pemilu serentak yang akah dilaksanakan pada tahun 2019, yaitu pemilu presiden untuk memilih pemimpin eksekutif dan legislative dilaksanakan secara serentak, bersamaan dihari dan waktu yang sama.

Dari berbagai persoalan tersebut, pemilu serentak 2019 tentu menjadi tantangan dan peluang bagi seluruh elemen bangsa dalam perbaikan sistem politik dan demokrasi di Indonesia, khususnya partai politik peserta pemilu. Agar pemilu serentak 2019 dapat terlaksana dengan baik diperlukan kesungguhan dari pemerintah dan anggota parlemen untuk tidak terjebak dalam politik oportunis dan pragmatis, penyelenggaraan pemilu serentak 2019 harus menjadi referensi sistem pemilu baru di Indonesia.

Dalam penelitian ini, penulis tertarik untuk melihat proses pelaksanaan Pendidikan Politik oleh Dewan Pimpinan 
Daerah (DPD) partai Gerindra Jawa Timur di Kabupaten dan Kota Mojokerto dalam menghadapi pemilu serentak 2019. Jika melihat hasil pemilu legislatif tahun 2014 yang lalu, Partai Gerindra merupakan partai dengan jumlah suara terbesar keempat setelah PKB, PDIP dan Partai Golkar di Jawa Timur. Sedangkan, pada pemilu serentak 2019 mendatang, visi partai Gerindra Jawa Timur adalah menjadi partai pemenang di Jawa Timur, dengan target memenangkan pilpres dengan suara 55\% di Jatim, meraih 4 juta suara Partai dan Caleg pada pemilihan legislatif 2019, meraih 24 kursi DPRD Jawa Timur pada pemilihan legislatif 2019, memenangkan 15 Kursi DPR RI pada pemilihan legislatif 2019, serta memenangkan 370 kursi DPRD $\mathrm{Kab} /$ Kota dalam pemilu legisatif 2019 (22\%). Selain itu, DPD Partai Gerindra Jawa Timur juga mengusung slogan "Setia Bersama Rakyat" sebagai upaya untuk melegitimasi bahwa seluruh perjuangan politik partai Gerindra dipersembahkan untuk kebaikan masyarakat di seluruh Jawa Timur.

Pelaksanaan Pendidikan Politik DPD Partai Gerindra Jawa Timur sebenarnya dilaksanakan dipuluhan titik Kabupaten dan kota di seluruh Jawa Timur akhir bulan Desember 2018 yang lalu. Namun, penulis hanya membatasi di dua titik, yaitu di Kabupaten Mojokerto dan Kota Mojokerto dalam penelitian ini, selain karena faktor teknis, kabupaten Mojokerto dan Kota Mojokerto merupakan dua wilayah kekalahan partai Gerindra pada pemilu tahun 2014 yang lalu, sehingga DPD Partai Gerindra Jawa Timur tentu akan fokus didua wilayah tersebut sebagai upaya strategis untuk meningkatkan perolehan suara di pemilu 2019 yang akan datang. Selain itu, pelaksanaan pemilu serentak juga menjadi tantangan dan peluang tersendiri bagi Partai Gerindra, jika peluang tersebut dapat dimanfaatkan dengan baik, bukan tidak mungkin keuntungan electoral dari coattail effect bisa diperoleh oleh partai Gerindra, karena mampu mengusung calon presiden dan wakil presiden dari partainya sendiri bersamaan dengan pelaksanaan pemilu legislatif.

Berdasarkan penjabaran diatas, penulis tertarik untuk mendeskripsikan bagaimana proses pelaksanaan pendidikan politik yang dilakukan oleh DPD partai Gerindra Jawa Timur di Kabupaten Mojokerto dan Kota Mojokerto dalam menghadapi pemilu serentak 2019, serta apa saja faktor penghambat dalam proses pelaksanaan pendidikan politik tersebut.

\section{Kerangka Teoiritis \\ Pendidikan Politik}

Secara harfiah istilah pendidikan dan politik merupakan dua hal yang berbeda, namun memiliki tujuan utama yang saling medukung satu sama lain. Pendidikan dapat dikatikan dengan proses transfer ilmu pengetahuan dan budaya, dan juga perkembangan keterampilan dan pelatihan yang diharapkan mampu membawa perubahan pada diri individu yang terdidik (Sudiarja, 2006:413). Sedangkan politik terkait dengan praktik kekuasaan yang berkenaan dengan pembuatan kebijakan publik. Karena keduanya sarat dengan distribusi nilai atau value dalam masyarakat, maka tidaklah sulit untuk memahami bahwa pendidikan dan politik adalah dua perangkat aktivitas yang kedepan akan terus terkait.

Pendidikan politik tersebut menurut Alfian (dalam Ahdiyana, 2009) merupakah upaya sadar untuk merubah proses sosialisasi politik di masyarakat sehingga mampu memahami nilai atau value yang ada dalam sistem politik ideal yang hendak dicapai. Secara umum, pendidikan politik bertujuan untuk mempersiapkan generasi penerus yang 
mampu menerima dan melanjutkan sistem nilai yaitu sistem politik, pola keyakinan dan sistem budaya, menyamakan sistem berfikir yang berpedomanan pada nilai-nilai, memantapkan diri dalam menjalankan sistem nilai-nilai religius, sekaligus melestarikan sistem nilai (Soemarno, AP. 2002). Sementara itu, dalam UU No 2 Tahun 2008 tentang partai politik mendefinisikan pendidikan politik merupakan proses pembelajaran dan pemahaman tentang hak, kewajiban, dan tanggung jawab setiap warga negara dalam kehidupan berbangsa dan bernegara.

\section{Partai Politik}

Partai politik selanjuntya disingkat parpol adalah sarana atau tempat bagi masyarakat untuk berkumpul, menyalurkan aspirasi, dan menyatakan pendapat politik. Sistem politik kita saat ini telah menempatkan parpol sebagai salah satu pilar penyangga demokrasi. Kehadiran partai politik dalam negara demokrasi tidak bisa lepas dari peran dan fungsinya, tidak hanya kepada konstituen yang dikelola tetapi juga kepada bangsa dan Negara, sehingga bisa dikatakan baik buruknya sebuah partai politik akan berdampak pada baik buruknya sebuah bangsa.

Dari pemahaman tersebut, secara umum partai politik dapat dimaknai sebagai kelompok yang terorganisasi, dengan anggota yang mempunyai orientasi, nilai, dan cita-cita yang sama. Tujuan kolompok ini jika dimaknai secara low level politic ialah untuk memperoleh kekuasaan dan merebut kedudukan negara (politik) dengan cara yang sah secara konstitusional untuk melaksanakan kebijaksanaankebijaksanaan yang mereka janjikan (Budiarjo, 2005: 60).

Sementara itu, dalam kepustakaan ilmu politik terkait peranan dan fungsi partai politik, dapat dikemukakan bahwa peran partai politik adalah (Gaffar dan Amal dalam Fadjar, 2013:18) :

a. Dalam proses pendidikan politik

b. Sumber rekrutmen calon pemimpin bangsa untuk mengisi posisi pejabat negara

c. Lembaga kepentingan masyarakat, dan

d. Penghubung antara masyarakat dan penguasa.

Dalam negara demokrasi modern, fungsi partai politik secara umum (Budiarjo, 2005: 163) adalah sebagai wadah untuk komunikasi politik, sosialisasi politik, dan sarana pengatur konflik.

\section{METODE PENELITIAN}

Metode yang digunakan dalam penelitian ini adalah metode deskriptif kualitatif, dimana data yang dikumpulkan umumnya bersifat kualitatif dan disajikan secara deskriptif. Data tersebut diperoleh dari hasil wawancara, pengamatan di lapangan, dokumen pribadi, dan dokumen resmi yang terkait dengan penelitian (Moeloeong, 2004: 131). Adapun teknik pengumpulan data dengan wawancara dan dokumentasi yaitu mengumpulkan data berdasarkan laporanlaporan dokumenter yang berkaitan dengan proses pelaksanaan pendidikan politik oleh DPD Partai Gerindra Jawa Timur di Kabupaten Mojokerto dan Kota Mojokerto.

Dalam penelitian ini, peneliti memfokuskan penelitian pada pendidikan politik yang dilakukan oleh DPD Partai Gerindra Jawa Timur kepada masyarakat di Kabupaten Mojokerto dan Kota Mojokerto, dengan fokus sebagai berikut:

a. Konsep dan program partai politik tentang pendidikan politik.

b. Materi dan metode pendidikan politik yang digunakan.

c. Faktor-faktor pendorong dan penghambat bagi partai politik dalam 
memberikan pendidikan politik kepada masyarakat.

Penelitian ini dilakukan di beberapa wilayah meliputi:

a. Kantor DPD Partai Gerindra Jawa Timur

b. Kantor DPC Kabupaten Mojokerto

c. Kantor DPC Kota Mojokerto

d. Hotel Ayola Kota Mojokerto

e. Hotel Raden Wijaya Kota Mojokerto

Waktu penelitian dilakukan pada bulan November - Desember 2018. Sedangkan untuk sumber data yang digunakan adalah data primer yang diperoleh dari lokasi penelitian, berupa hasil wawancara dengan informan penelitian dan selanjutnya didukung oleh data sekunder terkait dengan proses pelaksanaan pendidikan politik oleh DPD Partai Gerindra Jawa Timur di Kabupaten Mojokerto dan Kota Mojokerto. Data primer tersebut terdiri dari:

a. Hidayat, M.Si (Wakil ketua DPD Partai Gerindra Jawa Timur)

b. Arif Setiawan, S.Sos. (Ketua DPC Partai Gerindra Kabupaten Mojokerto)

c. Edwin (Ketua DPC Partai Gerindra Kota Mojokerto)

d. Peserta pelaksanaan pendidikan politik DPD Partai Gerindra Jawa Timur

\section{PEMBAHASAN}

Pendidikan politik sering disebut sebagai political forming karena mengandung intense dalam membentuk insan politik yang sadar akan kedudukan politiknya di kalangan masyarakat. Selain itu pendidikan politik juga bermakna "bildung" (pembentukan atau, pendidikan diri sendiri), karena kata tersebut mengandung pengertian pembentukan diri secara individu dengan kesadaran dan tanggung jawab sendiri untuk menjadi insan politik (Kartono, 1989: 13).

Partai politik berdasarkan UndangUndang Nomor 2 Tahun 2011 Tentang Partai Politik diartikan sebagai organisasi yang bersifat nasional dan dibentuk oleh sekelompok warga negara Indonesia secara sukarela atas dasar kesamaan kehendak dan cita-cita untuk memperjuangkan dan membela kepentingan politik anggota, masyarakat, bangsa dan negara, serta memelihara keutuhan Negara Kesatuan Republik Indonesia berdasarkan Undang-Undang Dasar Negara Republik Indonesia Tahun 1945. Partai politik yang ada di Indonesia wajib mengadakan sebuah pendidikan politik. Hal ini sesuai yang dicantumkan dalam Undang-Undang Nomor 2 Tahun 2011 pasal 31 ayat 1 bahwa partai politik wajib melakukan pendidikan politik bagi masyarakat, dengan bertujuan untuk meningkatkan kesadaran hak dan kewajiban masyarakat dalam kehidupan bernegara serta meningkatkan partisipasi politik dan membentuk budaya politik sesuai Pancasila.

Kewajiban partai politik untuk melaksanakan pendidikan politik tidak sekedar karena perintah konstitusi, lebih dari itu partai politik mempunyai tanggung jawab moral terhadap konstituen dan pendukungnya, selain itu perkembangan politik seperti perubahan sistem politik di Indonesia juga menjadi faktor penting dalam pelaksanaan pendidikan politik oleh partai politik khususnya DPD Partai Gerindra Jawa Timur.

Pemilihan Umum Serentak atau yang disebut dengan "concurrent elections" oleh Benny Geys didefinisikan sebagai sistem pemilu yang melangsungkan beberapa pemilihan pada satu waktu yang bersamaan (Electoral studies 25, 2006;652). Sistem Pemilu ini selain di pelopori oleh Amerika Serikat, juga banyak diterapkan dinegara-negara dengan Demokrasi yang sudah maju seperti di Eropa Barat. Di Asia Tenggara sendiri, Pemilu Serentak belum terlalu dikenal, namun pelaksanannya dapat dilihat di Filipina. Meskipun sistem Pemilu ini identik dengan negara 
Demokrasi maju, namun di Amerika Latin, sistem ini cukup populer diterapkan dinegara-negara basis sosialis, seperti Brazil, Bolivia, Peru, dan Venezuela.

Geys

(Andersen, bahwa salah satu keuntungan dilaksanakannya Pemilu serentak adalah pengaruh dan efeknya terhadap tingkat partisipasi pemilih. Seperti di Amerika misalnya, pelaksanaan pemilu serentak menunjukkan bagaimana pemilih ternyata lebih antuasias dengan Pemilu Kongres dan Pemilu Senat jika dilaksanakan serentak bersamaan dengan pemilihan presiden. Namun demikian, sistem pemilu serentak juga mempunyai pengaruh kurang positif terhadap pengetahuan pemilih, yaitu terbatasnya kemampuan "pemilih" dalam menganalisis dan memahami siapa calon yang tepat untuk menjadi pilihannya, sehingga mengakibatkan kecendrungan pemilih untuk ikut dengan keputusan mayoritas.

Perubahan sistem pemilu itulah yang melatarbelakangi DPD Partai Gerindra untuk melaksanakan pendidikan politik dibeberapa wilayah di Jawa Timur termasuk di Kabupaten Mojokerto dan Kota Mojokerto, hal ini terungkap dari wawancara peneliti dengan salah satu pengurus DPD Partai Gerindra Jawa Timur (Hidayat, M.Si), yang menyatakan bahwa salah satu alasan pelaksanaan pendidikan politik selain masuk dalam program kerja partai juga karena kebutuhan mendesak akibat diberlakukannya pemilu secara serentak, sehingga perlu adanya kegiatan dengan konstituen dan masyarakat di daerah daerah guna memperkuat konsolidasi kepartaian.

Pendidikan politik merupakan usaha sadar untuk mengubah proses sosialisasi politik masyarakat sehingga mereka menghayati dan memahami nilainilai yang terkandung dalam sistem politik ideal yang hendak dibangun. Metode penyampaian pendidikan politik pun dilakukan dengan cara berbeda, seperti untuk kader atau anggota partai dilakukan pertemuan secara intensif guna menanamkan loyalitas serta pembentukan sikap politik yang ideal guna menjalankan program partai yang telah ditentukan. Sementara itu, pendidikan politik untuk masyarakat dapat dilakukan secara langsung maupun tidak langsung, yakni melalui perantara media, baik media massa ataupun media eletronik yang ada. Dalam penelitian ini, penulis melihat bahwa pelaksanaan pendidikan politik oleh DPD Partai Gerindra Jawa Timur lebih banyak berorientasi kepeda pendidikan politik internal, atau politik untuk kader, anggota dan simpatisan partai.

Pelaksanaan Pendidikan Politik DPD Partai Gerindra Jawa Timur Kabupaten Mojokerto

Berdasarkan data yang diperoleh peneliti, pelaksanaan pendidikan politik DPD partai Gerindra Jawa Timur terlebih dahulu dilaksanakan di Kabupaten Mojokerto, berkerjasama dengan pengurus DPC Partai Gerindra Kabupaten Mojokerto sebagai panitia pelaksana ditingkat lokal.

\begin{tabular}{|c|c|c|c|c|}
\hline Tempat & $\begin{array}{l}\text { Hari, tanggal } \\
\text { pelaksanaan }\end{array}$ & $\begin{array}{l}\text { Jumlah } \\
\text { peserta }\end{array}$ & Materi & Narasumber \\
\hline $\begin{array}{c}\text { Hotel Ayola } \\
\text { Kota } \\
\text { Mojokerto }\end{array}$ & $\begin{array}{c}\text { Selasa, } 27 \\
\text { November } \\
2018\end{array}$ & $\begin{array}{c}270 \\
\text { peserta }\end{array}$ & $\begin{array}{ll}\text { - } & \text { Ideologi Partai } \\
\text { Gerindra dan } \\
\text { gerakan PPIR } \\
\text { - } \quad \text { Undang undang } \\
\text { PEMILU }\end{array}$ & $\begin{array}{ll}- & \text { Letjend (Purn) } \\
\text { Musa Bangun } \\
- & \text { Hidayat, M.Si } \\
- & \text { Ketua KPUD } \\
& \text { Kab. Mojokerto }\end{array}$ \\
\hline
\end{tabular}




\begin{tabular}{|l|l|l|l|}
\hline & & $\begin{array}{l}\text { Strategi } \\
\text { Pemenangan } \\
\text { Pemilu }\end{array}$ & \\
\hline
\end{tabular}

Sumber; Data Olahan Penulis, 2018

Kota Mojokerto

Selanjutnya pendidikan politik kedua DPD partai Gerindra Jawa Timur dilaksanakan di
Kota Mojokerto, berkerjasama dengan pengurus DPC Partai Gerindra Kota Mojokerto sebagai panitia pelaksana ditingkat lokal.

\begin{tabular}{|c|c|c|c|c|}
\hline Tempat & $\begin{array}{l}\text { Hari, tanggal } \\
\text { pelaksanaan }\end{array}$ & $\begin{array}{l}\text { Jumlah } \\
\text { peserta }\end{array}$ & Materi & Narasumber \\
\hline $\begin{array}{c}\text { Hotel Ayola } \\
\text { Kota Mojokerto }\end{array}$ & $\begin{array}{c}\text { Rabu, } 28 \\
\text { November } 2018\end{array}$ & $\begin{array}{c}150 \\
\text { peserta }\end{array}$ & $\begin{array}{ll}\text { - } & \text { Ideologi Partai } \\
\text { Gerindra dan gerakan } \\
\text { PPIR } \\
\text { - } \quad \text { Undang undang } \\
\text { PEMILU } \\
\text { - } \quad \text { Strategi Pemenangan } \\
\text { Pemilu }\end{array}$ & $\begin{array}{ll}- & \text { Letjend (Purn) } \\
& \text { Musa Bangun } \\
- & \text { Hidayat, M.Si } \\
- & \text { Ketua KPUD } \\
& \text { Kota Mojokerto }\end{array}$ \\
\hline
\end{tabular}

Sumber; Data Olahan Penulis, 2018

\section{Gabungan}

Selanjutnya

pelaksanaan

pendidikan politik ketiga DPD partai Gerindra Jawa Timur dilaksanakan di Kota Mojokerto, berkerjasama dengan pengurus DPC Partai Gerindra Kabupaten Mojokerto dan DPC Partai Gerindra Kota Mojokerto sebagai panitia pelaksana ditingkat lokal.

\begin{tabular}{|c|c|c|c|c|}
\hline Tempat & $\begin{array}{c}\text { Hari, tanggal } \\
\text { pelaksanaan }\end{array}$ & $\begin{array}{l}\text { Jumlah } \\
\text { peserta }\end{array}$ & Materi & Narasumber \\
\hline $\begin{array}{c}\text { Hotel Raden } \\
\text { Wijaya Kota } \\
\text { Mojokerto }\end{array}$ & $\begin{array}{c}\text { Ahad, } 23 \\
\text { Desember } 2018\end{array}$ & $\begin{array}{c}250 \\
\text { peserta }\end{array}$ & $\begin{array}{ll}\text { - } & \text { Kompas Jalan } \\
\text { Pemenangan } \\
\text { Partai Gerindra } \\
\text { - } \quad \text { Undang } \\
\text { undang } \\
\text { PEMILU } \\
\text { - } & \text { Strategi } \\
\text { Pemenangan } \\
\text { Pemilu }\end{array}$ & $\begin{array}{ll}\text { - } & \begin{array}{l}\text { Surokim } \\
\text { (Surabaya }\end{array} \\
\text { Survey } & \text { Center) } \\
\text { - } & \text { Hidayat, } \\
\text { M.Si } \\
\text { - } \quad \text { Ketua KPUD } \\
\text { Kab. } \\
\text { Mojokerto }\end{array}$ \\
\hline
\end{tabular}

\section{Sumber; Data Olahan Penulis, 2018}

Dari tabel yang disajikan oleh penulis, dapat dipahami bahwa DPD Partai Gerindra Jawa Timur telah melaksanakan Pendidikan Politik di Hotel Ayola Kota Mojokerto selama tiga hari, dengan jumlah peserta dihari pertama sebanyak 270 orang pada hari selasa tanggal 27 November 2018, hari kedua sebanyak 150 orang pada hari rabu tanggal 28 November 2018. Dari 270 peserta dihari pertama dan 150 peserta yang hadir, rata rata peserta yang hadir berasal dari simpatisan dan kader partai Gerindra, hal ini sesuai dengan pernyataan ketua DPC Partai Gerindra Kabupaten Mojokerto, Arif Setiawan yang juga menjadi panitia tingkat lokal dalam kegiatan tersebut, jumlah peserta yang hadir berasal dari simpatisan partai, relawan pemenangan calon presiden, kader partai, anggota partai, dan sebagian Purnawirawan Pejuang Indonesia Raya 
(PPIR) Kabupaten Mojokerto sebagai sayap partai. Hal yang sama juga terjadi di pelaksanaan pendidikan politik hari ketiga di Hotel Raden Wijaya Kota Mojokerto sebanyak 250 peserta pada hari Ahad 23 Desember 2018.

Jika merujuk pada hasil wawancara tersebut, serta memperhatikan latarbelakang peserta yang hadir dapat dipahami bahwa pelaksanaan pendidikan politik di Kabupaten Mojokerto dan Kota Mojokerto selama tiga kali lebih banyak berorientasi pada pendidikan politik internal. Hal ini diperkuat oleh keterangan saudara Hidayat, sebagai panitia pelaksana dari DPD Partai Gerindra Jawa Timur bahwa kegiatan pendidikan politik di Kabupaten Mojokerto memang bertujuan untuk penguatan konsolidasi kader partai dalam menghadapi Pemilu serentak 2019. Hal ini tentu selaras dengan tujuan partai politik yaitu untuk membentuk dan menumbuhkan kepribadian politik dan kesadaran politik, sebagaimana juga bertujuan untuk membentuk kemampuan dalam berpartisipasi pada individu agar menjadi partisipasi politik yang positif (Prihatmoko, 2003: 180).

Selain itu, hasil penelitian juga menunjukkan bahwa materi yang disampaikan pada kegiatan pendidikan politik tersebut, lebih mengarah pada penguatan ideology dan konsolidasi internal partai, pemahaman terhadap tahapan dan aturan pemilu serantak, strategi pemenangan partai Gerindra, serta peluang dan tantangan partai Gerindra dalam menghadapi pemilu serentak tahun 2019. Hal ini dapat dilihat dari materi yang disampaikan pertama kali, yaitu penguatan ideology kepartaian, kemudian materi selanjutnya lebih bersifat pemahaman terhadap sistem pemilu serantak, yaitu bagaimana tahapan dan aturan aturan yang harus diikuti oleh seluruh elemen masyarakat agar terhindar dari kasus hukum yang disebabkan oleh aturan kepemiluan. Sementara itu, untuk memperkuat strategi pemenangan, dalam pelaksanaan pendidikan politik itu juga terdapat materi dari lembaga survey dan konsultan politik (Surabaya Survey Center) yang memaparkan hasil survey dan kajian bagaimana peluang dan tantangan yang bisa dimanfaatkan oleh Partai Gerindra dalam pelaksanaan pemilu serentak tahun 2019.

Rangkaian kegiatan dan substansi materi yang disampaiakan pada pelaksanaan pendidikan politik tersebut, tentu sebagai upaya yang bertujuan untuk membentuk manusia menjadi partisipan yang bertanggung jawab dalam politik (Kartono, 1989 : 14). Pendidikan politik ini juga merupakan aktifitas yang terorganisir dan efektif yang dilakukan secara sengaja dan sistematis bertujuan untuk membentuk individu agar mampu menjadi partisipan yang bertanggung jawab secara etis/moral dalam mencapai tujuan-tujuan politik. Pendidikan politik merupakan pendidikan orang dewasa dengan jalan menyiapkan kader-kader untuk pertarungan politik dan mendapatkan penyelesaian politik agar menang dalam perjuangan politik (Kartono, 1989: 14).

Penelitian ini juga mengkonfirmasi bahwa harapan pasca pelaksanaan kegiatan pendidikan politik ini bisa semakin menumbuhkan kesadaran politik bagi seluruh simpatisan, relawan, kader, dan anggota partai Gerindra yang berasal dari pengetahuan, orientasi, dan nilai nilai yang membentuk wawasan politik individu jika dikatikan dengan tinjauan terhadap kekuasaan politik. Kesadaran politik dapat dicapai melalui arahan politik secara langsung, baik melalui jalur formal maupun nonformal, melalui penjelasan-penjelasan politik, usahausaha bimbingan dan pengajaran politik langsung, yang dilakukan oleh para pemikir dan pemimpin-pemimpin politik. Pengalaman politik yang didapatkan 
melalui partisipasi politik. Kesadaran muncul melalui dialog-dialog kritis.

\section{Faktor Penghambat}

Peneliti menemukan beberapa faktor penghambat dalam proses pelaksanaan pendidikan politik oleh DPD Partai Gerindra Jawa Timur di Kabupaten Mojokerto dan Kota Mojokerto. Pertama, metode komunikasi yang kurang tepat, penyampaian pendidikan politik yang dilakukan pada saat kegiatan terkesan menggunakan metode komunikasi satu arah, yaitu metode komunikasi dari komunikator, dalam hal ini narasumber dari partai kepada penerima pesan yaitu para simaptisan atau relawan masyarakat. Metode komunikasi seperti ini cenderung bersifat Top down yang jika dipahami sebagai bentuk pemaksaan stimulus yang justru bisa jadi sama sekali tidak menjamin bisa dipahami dengan baik oleh masyarakat, istilah kasar yang muncul adalah komunikasi totalitarianis. Secara teori, pola komunikasi tersebut justru tidak bisa memberi pengaruh yang signifikan terhadap kecerdasan politik masyarakat, karena dalam metode komunikasi satu arah tentu tidak terjadi proses dialog dan diskusi antara komunikator atau penyampai pesan dengan penerima pesan, padahal prasyarat utama dalam membentuk kesadaran politik adalah melalui dialogdialog kritis yang dibangun pada saat kegiatan pendidikan politik.

Kedua, keterbatasan waktu, padatnya materi yang disampaikan dalam waktu yang sangat singkat tentu menyebabkan substansi materi bisa tidak sampai dibenak para peserta yang hadir. Jika memperhatikan aspek aspek yang perlu dibangun dalam pendidikan politik, yaitu aspek kognitif, afektif, dan psikomotorik, suasana ruangan yang santai tanpa tekanan kapan harus selasai adalah pra syarat utama, terdapat empat materi dalam waktu kurang dari satu hari tentu bisa menyebabkan apa yang disampaikan oleh narasumber menjadi sia-sia, apalagi padatnya materi terkadang juga harus terpotong karena factor-faktor teknis seperti molornya waktu pembukaan acara, absensi sesuai dengan kartu identitas, pembagian alat peraga kampanye, serta antri pada saat istiraha, sholat dan makan.

\section{SIMPULAN}

Dalam menghadapi pemilu serentak 2019, Dewan Pimpinan Daerah (DPD) Partai Gerindra Jawa Timur melaksanakan program pendidikan politik di Kabupaten Mojokerto dan Kota Mojokerto sebagai upaya untuk penguatan ideology dan konsolidasi partai. Orientasi pendidikan politik ini masih berorientasi pada penguatan kelembagaan internal partai, yaitu pendidikan politik yang disampaikan pada kalangan internal seperti simpatisan, relawan, kader, dan anggota partai Gerindra sendiri.

Materi yang disampaikan pada kegiatan pendidikan politik tersebut, lebih mengarah pada penguatan ideology dan konsolidasi internal partai, pemahaman terhadap tahapan dan aturan pemilu serantak, strategi pemenangan partai Gerindra, serta peluang dan tantangan partai Gerindra dalam menghadapi pemilu serentak tahun 2019.

Selain itu, dalam penelitian ini juga berhasil mengungkap hambatan yang dihadapi pada saat pelaksanaan pendidikan politik yaitu metode komunikasi yang kurang tepat pada saat menyampaikan materi, masih cenderung bersifat top down sehingga tidak muncul komunikasi dua arah secara maksimal. Hambatan selanjutnya lebih bersifat teknis, yaitu keterbatasan waktu akibat padatnya materi yang terkadang juga harus terpotong karena factor-faktor teknis seperti molornya waktu pembukaan acara, absensi sesuai dengan 
kartu identitas, pembagian alat peraga kampanye, serta antri pada saat istiraha, sholat dan makan.

\section{DAFTAR PUSTAKA}

Andersen, David J. 2011. "Pushing the Limits of Democracy: Concurrent Elections and Cognitive Limitations of Voters. PhD Dessertation, (New Jersey: The State University of New Jersey).

Arikunto, Suharsimi. 2010. Prosedur Penelitian Suatu Pendekatan Praktik. Jakarta: PT Rineka Cipta.

Badan Penelitian dan Pengembangan HAM. 2011. Peran Partai Politik Dalam Memberikan Pendidikan Politik Bagi Masyarakat. Jakarta: Kementerian Hukum dan HAM RI.

Basrowi dan Suwandi. 2008. Memahami Penelitian Kualitatif. Jakarta: PT Rineka Cipta.

Budiarjo, Miriam. 1986. Dasar-Dasar Ilmu Politik. Edisi kedua. Jakarta: PT Gramedia

Firmanzah. 2011. Mengelola Partai Politik Komonikasi dan Positioning Ideologi Politik di Era Demokrasi. Jakarta : Yayasan Buku Obor Indonesia

Geys, Benny. 2006. "Explaining Voter Turnout: A Review of Aggregate level Research." Dalam Electoral Studies 25

Haris, Syamsuddin. 2014. Partai, Pemilu, dan Parlemen Era Reformasi. Jakarta : Yayasan Pustaka OBOR.
Kantaprawira, Rusadi. 2004. Sistem Polilik Indonesia: Suatu Model Pengantar. Bandung: Sinar Baru Algensindo.

Kartono, Kartini. 1996. Pendidikan Politik Sebagai Bagian Pendidikan Orang Dewasa. Bandung: CV. Mandar Maju.

Labolo, Muhadam. 2015. Partai Politik Dan Sistem Pemilihan Umum Di Indonesia : Teori, Konsep dan Isu Strategis. Jakarta. PT. Raja Grafindo Persada.

Mukthie Fadjar, Abdul. 2013. Partai Politik Dalam Perkembangan Ketatanegaraan Indonesia. Malang: Setara Press (Kelompok Penerbit Intrans).

Muliansyah A. Ways. 2015. Political : Ilmu Politik, Demokrasi, Partai Politik \& Welfare State. Yogyakarta. Buku Litera.

Moloeng, Lexy J. 2004. Metode Penelitian Kualitatf. Bandung: Remaja Rosda Karya.

Pamungkas, Sigit. 2012. Partai Politik : Teori dan Praktik di Indonesia. Yogyakarta : Institute for Democracy and Welfarism.

Prihatmoko, Joko. 2003. Pemilu 2004 dan Konsolidasi Demokrasi. Semarang: LP21 Press

Surbakti, Ramlan. 2010. Memahami Ilmu Politik. Jakarta. PT. Grasindo. Sumber lainnya

AD / ART Partai Gerindra. Rancangan Cetak Biru DPD Partai Gerindra Jawa Timur 2017 - 2019. 